\title{
ALLAH DAN SENI MENURUT PEMIKIRAN GEORG WILHELM FRIEDRICH HEGEL DAN JONATHAN EDWARDS
}

\author{
Jimmy Pardede \\ Gereja Reformed Injili Indonesia Bandung
}

ABSTRAK: Kenikmatan akan keindahan artistik jarang dianggap kudus dan sakral dalam kebudayaan sekuler kita. Keilahian dan kesalehan dianggap sebatas iman personal; sementara seni sebagai suatu bahasa universal akan kenikmatan manusia. Hegel mencoba untuk menampilkan keilahian, "Allah," dan agama dengan cara yang dapat diterima oleh orang-orang sekular sejamannya dan masyarakat deistik-romantik dengan mensekularkan tiga hal ini. Sekalipun terdapat sisa-sisa dari gambaran klasik kekristenan akan Allah sebagai pencipta dan penopang segala sesuatu, tetapi gambaran sekuler akan Allah ini memiliki banyak permasalahan yang tak dapat dibereskan di banyak tempat, dalam konsep Hegel akan keilahian dan "Allah yang sekuler." Itu sebabnya upayanya untuk membawa "spiritualitas" ke dalam diskusi akan seni dan keindahan harus dikritik dari perspektif dari Teologi Jonathan Edwards mengenai kemuliaan Allah. Dari perspektif kedua raksasa ini, perenungan akan seni, keindahan dan spiritualitas di dalam tren kekristenan yang populer di jaman kita perlu ditelaah. 
KATA KUNCI: seni, absolut, abstraksi, Hegel, Edwards, ad intra, ad extra.

ABSTRACT: The enjoyment of artistic beauty has seldom been considered holy and sacred in our secular culture. Divinity and piety is considered as a matter of personal faith; whereas art is a matter of a universal language of human enjoyment. Hegel tries to introduce divinity, "God," and religion in a way acceptable to his secular contemporaries and deistic-romantic societies by secularizing these three. There is reminiscence of the classical picture of Christianity of God as the creator and sustainer of all, but the secularized picture of God has too many irreconcilable problems in Hegel's concept of divinity and "secular God." Therefore his effort to bring "spirituality" in the discussion of art and beauty had to be criticized from the perspective of Jonathan Edwards' theology of God's glory. From these two giants' perspectives, the contemplation art, beauty, and spirituality in the popular trends of Christianity in our day must then be examined.

KEYWORDS: art, absolute, abstraction, Hegel, Edwards, ad intra, ad extra.

\section{Introduksi}

Seni merupakan bagian yang sangat penting dari kehidupan manusia. Tetapi pentingnya seni hanya dapat dirasakan setelah munculnya kekosongan hidup yang diakibatkan oleh absennya seni 
ketimbang kesadaran akan keberadaan Allah yang mengekspresikan keindahan-Nya untuk dinikmati oleh manusia di dalam seni yang sejati. Apakah yang menjadikan seni sedemikian sulit untuk dihargai dengan tepat? Penyebabnya tidak lain adalah kehidupan sekuler yang meniadakan Tuhan di dalam segala hal yang duniawi telah meletakkan seni di bawah "takhta" dunia yang netral di mana Tuhan tidak dapat, atau lebih tepatnya, tidak tertarik untuk bertakhta. Di dalam dunia sekuler seni tidak boleh dikaitkan dengan doktrin Kristen. Seni tidak boleh ditafsirkan secara teologi. Seni tidak boleh disempitkan ke dalam realita rohani dari sudut pandang Kristen. Dunia sekuler mengenal seni itu sebagai sesuatu yang netral dan tidak berkait dengan isu-isu yang dibahas oleh gereja. Karena itu keterkaitan seni dengan yang absolut menjadi sesuatu yang tidak lagi dibahas, atau kalaupun dibahas akan dibahas dengan cara yang sekadarnya untuk meletakkan label "rohani" kepada berbagai jenis seni yang sebenarnya tidak dimaksudkan untuk diapresiasi dengan merenungkan muatan rohani di dalamnya. Tulisan ini mencoba untuk menunjukkan bagaimana usaha Hegel untuk mengaitkan seni dengan yang mutlak di dalam kerangka pikir modern akhirnya hanya menundukkan yang absolut ke bawah keindahan dan seni, atau menundukkan seni hanya sebagai sarana menuju pernyataan yang lebih sempurna; dan membandingkan usaha ini dengan konsep Jonathan Edwards yang meletakkan tujuan keindahan dan seni di dalam karya penciptaan Allah. Di dalam tulisan ini penulis berusaha untuk memberikan argumen melalui dua pemikir ini bahwa, kecuali 
seni dikaitkan dengan Allah, maka seni menjadi sesuatu yang tidak akan pernah memberikan kepuasan sejati sebagaimana seharusnya di dalam rancangan Allah.

\section{Keindahan dan Abstraksi}

Mencoba membaca konsep apapun dari Hegel tentu tidak mungkin lepas dari apa yang dikemukakannya sebagai salah satu konsep dasarnya, yaitu dialektika. Dialektika Hegel sering disalahmengerti sebagai pengertian tiga tahap "tesis-antitesissintesis." Ini merupakan suatu kesalahan karena sebenarnya orang yang mengemukakan konsep ini adalah Fichte. Gustav Mueller memberikan dua argumen mengenai kesalahpahaman yang dimulai oleh kesalahpahaman Karl Marx di dalam membaca Hegel. 1 Yang pertama adalah Hegel tidak pernah menulis konsep ini dalam seluruh karyanya kecuali dalam salah satu pengantar karyanya dimana konsep ini dianggap oleh Hegel sebagai konsep Fichtean. Lalu yang kedua adalah fakta bahwa murid terbaik Hegel sendiri, Karl Rosenkranz, tidak pernah melihat konsep ini sebagai konsep milik gurunya. ${ }^{2}$ Konsep dialektika Hegel harus dimengerti sebagai suatu usaha untuk mengerti kontradiksi-kontradiksi sebagai sesuatu yang dilihat secara parsial. Keberadaan yang tinggi dan utuh merupakan keberadaan yang merupakan realita sejati yang bersifat

\footnotetext{
1 Gustav Mueller, "The Hegel Legend of 'Thesis - Antithesis - Synthesis'," The Hegel Myths and Legends, ed. Jon Stewart (Evanson: Northwestern University Press, 1996), 304.

2 Ibid., 303.
} 
utuh dan tidak parsial. Namun pemahaman logis dari pengamatan filosofis yang gagal melihat keutuhan ini akan mendeteksi banyak kontradiksi-kontradiksi yang sebenarnya bukan kontradiksi bila melihat keadaan realita sebagaimana realita tersebut ada. ${ }^{3}$ Konsep dialektika ini, bila dikaitkan dengan seni, merupakan pengertian yang melihat bagaimana seni merupakan sesuatu yang berbeda dari kehidupan sehari-hari, namun bukan merupakan abstraksi dari kehidupan sehari-hari. ${ }^{4}$ Kesadaran akan persepsi juga merupakan sesuatu yang bergerak secara dialektika. Persepsi yang menangkap apa yang terlihat secara langsung harus dibedakan dengan bila persepsi menangkap apa yang really is. ${ }^{5}$

Pembedaan, tetapi bukan abstraksi mutlak antara seni dan kehidupan mewarnai pembahasan Hegel dalam Lectures-nya. Seni akan membukakan seseorang kepada yang absolut. ${ }^{6}$ Tetapi bagaimanakah kesadaran seseorang akan yang absolut tersebut dapat terjadi? dan mengapa kontemplasi atas karya seni dapat menjadi pembuka akan kesadaran diri ini? Dua pertanyaan ini akan dibahas di dalam bagian selanjutnya.

3 Lihat misalnya pembahasan Gustav Mueller, 302. Juga pembahasan dari H. S. Harris, Hegel: Phenomenology and System (Indianapolis: Hackett Publishing Company, 1995), 25.

4 Ibid., 86.

5 Ibid., 25.

6 Disimpulkan oleh Michael Inwood, pengedit dan pemberi komentar atas Lectures on Aesthetic Hegel. Dapat dilihat dalam introduksi atas karya Georg Hegel, Introductory Lectures on Aesthetics (London: Penguin, 1993), xviii. 


\section{Yang Absolut dan Pernyataan Diri}

Sebelum masuk ke dalam pembahasan mengenai seni, perlu dilakukan secara singkat pembahasan mengenai konsep "absolut" Hegel dan pernyataan diri dari yang absolut tersebut. Hegel mengaitkan konsep yang absolutnya dengan allah. Menurut Paul Hidayat, bagi Hegel allah adalah Absolute Spirit yang di dalamnya seluruh realita ada. ${ }^{7}$ Pemahaman akan perbedaan realita dan allah harus dimengerti secara dialektikal, yaitu seperti sesuatu yang paradoks, tetapi demikianlah cara allah menyatakan diri, yaitu dengan konsep negasi yang adalah ...the othering of [h]imself. Allah, bagi Hegel, adalah Geist (Mind), ${ }^{9}$ dan dalam konsep mind yang absolut ini, Hegel memberikan fokus kepada sifat "ide" dari absolute mind ini. ${ }^{10}$ Maka, bagi Hegel, allah, atau absolute mind, merupakan Allah yang bersifat subyektif, memiliki kemampuan untuk berpikir, memiliki kesadaran, dan ada sebagai person. ${ }^{11}$ Yang absolut ini menyatakan diri dengan pergerakan dialektikal dimana yang absolut menjadi keberadaan yang lain dari dirinya, yaitu keseluruhan keberadaan ini. Maka, dengan demikian, seluruh keberadaan

\footnotetext{
7 Paul Hidayat, 'Hegel and the Doctrine of the Trinity,' God's Fiery Challanger for Our Time: Festschrift in honor of Stephen Tong, ed. Benyamin Intan (Jakarta: Reformed Center for Religion and Society, 2007), 88.

8 Ibid., 88.

9 Kebanyakan penerjemah lebih senang menggunakan kata "mind" ketimbang "spiriti" untuk memberikan pemisahan antara pemahaman secara religius dengan pemahaman filosofis Hegelian. Lihat misalnya H. B. Acton, "Hegel," The Encyclopedia of Philosophy, vol. 3, ed. Paul Edwards (New York: Macmillan, 1967). Maka dalam tulisan ini juga akan dipakai "mind."

10 Hidayat., 95.

11 Ibid., 93.
} 
merupakan the othering of himself, sebagaimana dibahas diatas. Kesadaran akan hal ini dibukakan kepada manusia melalui agama natural, Religion of Art, dan filsafat. Melalui ketiga hal ini manusia mengalami apa yang disebut dengan ...the development of human consciousness of God, which is the becoming actual of God's own consciousness in human consciousness. ${ }^{12}$

Jika demikian, alam merupakan pewahyuan dari Allah, tetapi juga merupakan pewahyuan yang dilihat sebagai suatu bentuk panen-theisme. Hal ini dilihat oleh Paul Hidayat yang menganggap konsep Hegel mengenai ciptaan sebagai suatu revelation of God yang juga adalah extension or manifestation of God. ${ }^{13}$ Pengertian ini diperoleh melalui melihat konsep Hegel yang melihat alam sebagai suatu "otherness of God" yang, menurut istilah Hegel sendiri, selain bersifat without God dan Godlessly, tetapi juga adalah otherness which is to be thought of in God.

Pernyataan diri yang absolut ini dinyatakan, salah satunya, melalui seni. Maka, dengan memakai seni sebagai pernyataan diri, seni merupakan sesuatu yang memiliki fungsi yang tidak dapat dibedakan secara mutlak dari agama. Hegel, karena itu, memakai istilah Religion of Art. Hegel mengatakan:

Through the Religion of Art spirit has passed from the form of substance into that of subject; for art brings out its shape and form, and imbues it with the nature of action, or establishes in it the selfconsciousness which merely disappears in the awesome substance

\footnotetext{
12 Ibid., 89.

13 Ibid., 98.
} 
and in the attitude of simple trust does not itself comprehend itself. ${ }^{14}$

Jika seni merupakan cara pernyataan diri yang absolut, maka apakah yang membuat seni menghasilkan sesuatu yang indah? Pembahasan Hegel dalam Lectures-nya akan menjadi fokus pembahasan selanjutnya.

\section{Yang Absolut dan Seni}

Kesulitan dalam melihat natur dari seni dan keindahan menurut konsep Hegel adalah kesulitan untuk melihat melampaui apa yang secara segera dipersepsi. Persepsi dan sense memang diperlukan, tetapi bukan makna dari keindahan itu sendiri karena sesuatu yang secara immediate dipersepsi merupakan sesuatu yang hanya merupakan permukaan dari apa yang seharusnya dirasakan. ${ }^{15}$ Persepsi dalam pemikiran Hegel merupakan sesuatu yang kompleks karena membedakan secara tajam antara momen kesadaran yang subyektif dan obyektif ke dalam level "what really is" dan what "immediately appears."16 Memahami realita yang sesungguhnya, bagi Hegel, berarti memahami realita secara unity dimana segala sesuatu memiliki real ground in the whole systems of things. ${ }^{17}$ Keberadaan inilah yang adalah keberadaan dari sang absolut menyatakan diri, dimana

\footnotetext{
14 Georg Hegel, The Phenomenology of Mind, terj. J. B. Baillie (Mineola: Dover Publications, 2003), 438.

15 G. W. F. Hegel, Introductory Lectures on Aesthetics (London: Penguin Classics, 1993), 43.

16 H. S. Harris, Hegel: Phenomenology and System (Indianapolis: Hackett Publishing Company, 1995), 25.

17 Ibid., 26-27.
} 
kesadaran akan diri yang absolut ini yang dinyatakan, baik melalui agama, seni, maupun filsafat. Maka, jikalau seni dipandang sebagai cara membangkitkan kesadaran akan sang absolut, seni membangkitkan keindahan di dalam kesadaran ini. Keindahan, yang adalah suatu realisasi dari kesadaran ini, tidak dimaksudkan terjadi dalam bentuk yang parsial, yaitu direfleksikan dan disimpulkan dari konsep keindahan saja tanpa menyentuh karya seni; tetapi merupakan sesuatu yang harus menyentuh sebuah karya seni untuk tidak menjadi keindahan yang abstrak. Hegel membahas mengenai dua sisi kesalahan dalam science of art yang melihat keindahan dan seni, yaitu yang hanya melihat karya seni sebagai suatu produk, atau yang melihat keindahan secara abstrak sebagai suatu pengantar untuk melihat seni secara konkret dan tidak sambil melakukan abstraksi. ${ }^{18}$

Sebelum melanjutkan ke pembahasan mengenai abstraksi dan konkret, pertama akan dibahas terlebih dahulu mengenai pembagian antara yang universal dan partikular dan kaitannya dengan konsep keindahan dalam seni. Hegel membahas tentang pengertian Plato mengenai particularity dan universality:

It is well known that Plato was the first to require of philosophical study, in a really profound sense, that its objects should be apprehended, not in their particularity, but in their universality, in their genus, in their own nature and its realization: inasmuch as he affirmed that the truth of things did not consist in individual good actions, true opinions, beautiful human beings or works of art, but in

18 Pembahasan mengenai science of art dapat dilihat dalam Hegel, Lectures, 17. 
goodness, beauty, truth themselves. ${ }^{19}$

Dan dengan demikian, maka:

...if the beautiful in fact to be known according to its essence and conception, this is only possible by help of the thinking idea, by means of which the logico-metaphysical nature of the Idea as such, as also that of the particular Idea of the beautiful enters into the thinking consciousness. ${ }^{20}$

Apakah yang indah tersebut merupakan sesuatu yang bersifat universal? Ataukah seni merupakan jalan menuju yang universal untuk dapat menyatakan keindahan universal? Hegel berpendapat bahwa konsep filosofis mengenai keindahan merupakan sesuatu yang mencakup dua ekstrem, yaitu baik universalitas yang bersifat metafisika, maupun determinateness of real particularity. ${ }^{21}$ Memisahkan kedua hal ini akan mengakibatkan kepada pengertian yang merupakan suatu abstract Metaphysics. ${ }^{22}$ Sepertinya Hegel melihat sisi content dari seni sebagai suatu partikular yang memuat form yang adalah penyataan dari yang absolut. Tetapi pengertian ini merupakan pembacaan dari kaum formalis yang dibawa kepada pembacaan Hegel. ${ }^{23}$ Hegel, sebaliknya, melihat kesatuan antara content dan form

\footnotetext{
19 Ibid., 25.

20 Ibid.

21 Ibid.

22 Ibid.

23 Nicholas Wolterstorff, "Art and Aesthetic: The Religious Dimension," The Blackwell Guide to Aesthetics, ed.Peter Kivy (Oxford: Blackwell, 2004), 325-338, membahas pemikiran dari Clive Bell, seorang formalist yang memercayai adanya yang absolut dibalik sebuah karya seni. Perasaan ini merupakan perasaan yang muncul akibat adanya kaitan dengan yang absolut. Bahkan, menurut Bell, pembahasan mengenai keberkaitan dengan yang absolut merupakan
} 
dalam melihat universalitas dan partikularitas. Keseluruhan seni dapat dilihat sebagai suatu partikularitas yang menuju kepada universalitas. Partikularitas diperlukan karena seni merupakan sesuatu yang memiliki aspek sense, walaupun dia menganggap bahwa ...sensuous aspect of the work of art has a right to existence only in as far as it exist for man's mind...24

\title{
Abstraksi dan Konkret
}

\author{
Konsep "Abstraksi" dalam terminologi Hegelian merupakan \\ suatu konsep yang menjelaskan keterpisahan suatu konsep dari yang \\ absolut sehingga konsep tersebut menjadi bagian yang terlepas dari
}

pembahasan inti dari seni. Jawaban mengenai emosi yang muncul, dan mengapa emosi tersebut muncul ketika seseorang mengontemplasi seni merupakan jawaban yang juga menjawab pertanyaan mengenai natur dari seni. Meskipun Wolterstorff memberikan fokus pembahasannya mengenai kaitan antara form dan content dari seni menurut Bell. Wolterstorff memberikan kritik bahwa pemikiran Bell mengenai yang absolut ini merupakan pemikiran yang terpengaruh dengan pemikiran Plotinus. Misalkan, di dalam pemikiran Bell, jika seseorang ingin mengontemplasi seni, orang tersebut harus menyadari bahwa perasaan emosi estetis ini merupakan perasaan yang tidak muncul karena content dari seni tersebut, misalnya nilai historis maupun kegunaan yang berada di luar seni itu sendiri. Keberadaan dunia materi ini tidak dapat dianggap sebagai penyebab munculnya emosi estetika. Maka, menurut Bell, keberadaan seni sejati itu adalah dalam form yang dimilikinya, atau dengan menggunakan istilah Bell, significant form. Keberadaan seseorang yang mengalami emosi estetika ketika melakukan perenungan terhadap suatu karya seni, bila emosi tersebut merupakan emosi estetika sejati, terjadi karena bagian dari "yang absolut" dalam diri kita menyatu dengan bagian dari "yang absolut" yang menyatakan diri melalui karya seni. Equivalen dari pemikiran Clive Bell ini terdapat dalam pemikiran John Hick. John Hick menganggap bahwa agama-agama sebenarnya merupakan jalan menuju kepada satu realita ultimat yang sama. Meskipun nampaknya sama, tetapi Clive Bell menganggap seni sebagai jalan yang lebih tepat ketimbang agama karena agama tidak murni menawarkan emosi dan telah dicampurkan dengan dogma dan doktrin. Karena itu, seni lebih tepat untuk mengalami keadaan ekstatik dalam menikmati emosi estetika karena seni merupakan sesuatu yang bebas dari segala macam content doktrinal. Pemikiran Bell yang mengaitkan seni dengan sang absolut dalam kerangka pikir seorang formalist membuat seni menjadi semacam "pewahyuan" dari sang absolut dimana sang absolut dan form dari seni tersebut merupakan sesuatu yang tidak dapat dipisahkan.

24 Hegel, Lectures, 43. 
keseluruhan. Sebaliknya, konkret dimengerti sebagai sesuatu yang parsial, tetapi yang secara utuh termasuk di dalam universalitas. Bagaimana kaitannya dengan seni dan keindahan? Hegel mengatakan bahwa keindahan merupakan reaksi dari thinking consciousness ketika kesadaran akan yang absolut itu muncul. Dengan demikian, seni merupakan suatu bentuk partikular yang konkret bila dilihat dalam hal ini. Seni menjadi sesuatu yang abstrak kalau seni tersebut menjadi sesuatu yang ditujukan untuk sesuatu yang lain. Seni, bila dilihat sebagai suatu "cara" untuk mencapai suatu "tujuan" diluar seni itu sendiri membuat seni menjadi terabstraksi dari keberadaan sejatinya. Menentang konsep seni sebagai suatu "cara," Hegel mengatakan,

...it is necessary to maintain that art has the vocation of revealing the truth in the form of sensuous artistic shape, of representing the reconciled antithesis just described, and, therefore, has its purpose in itself, in this representation and revelation. For other objects, such as instruction, purification, improvement, pecuniary gain, endeavour after fame and honour, have nothing to do with the work of art as such, and do not determine its conception. ${ }^{25}$

Dengan demikian, posisi seni adalah sebagai suatu perantara yang tidak dapat diabstraksikan dan menjadi bagian dari yang absolut ketika ia menyatakan diri. Perlu kita ingat bahwa konsep "wahyu" dari Hegel merupakan sesuatu yang menjelaskan bahwa sang absolut dan "sarana" pewahyuan merupakan suatu kesatuan yang dapat

25 Ibid., 61. 
dilihat dalam kerangka worldview panentheistic. ${ }^{26}$

Abstraksi berikutnya adalah abstraksi dalam hal konsep, baik itu seni sebagai content, maupun konsep keindahan sebagai sesuatu yang terlepas dari seni. Keindahan menjadi sesuatu yang diabstraksikan bila dilihat sebagai suatu konsep yang terpisah dari seni karena dengan abstraksi sedemikian, maka keindahan tidak lagi menjadi "jalan tengah" bagi negasi-negasi atau antitesis dalam realita seperti: self-concentrated-mind dan actual nature, external phenomena dan inner subjective feelings dan emosi. ${ }^{27}$

Jika demikian, seperti apakah pengertian yang konkret bagi Hegel? Untuk menjawab hal ini, kita perlu kembali mengingat kaitan antara realita dan ide absolut. Seni merupakan suatu keberadaan yang merupakan suatu proses dari ide absolut kepada representasi dari yang absolut dalam bentuk yang dapat ditangkap oleh sense. Sebagaimana telah dibahas di atas pada bagian "Yang Absolut dan Pernyataan Diri," yang absolut, atau ide absolut, menegasi diri dengan menjadi realita yang merupakan "The otherness of God." Maka, seni merupakan suatu tahap dimana sang absolut menyatakan diri kepada manusia, atau lebih tepatnya, menjadikan keberadaan atau realita sebagai realita yang sadar akan keberadaan ide absolut, dengan ...sensuous representation of the absolute self. ${ }^{28}$ Demikianlah keindahan yang ditangkap oleh panca indera merupakan suatu

\footnotetext{
26 Lihat bagian mengenai "Yang Absolut dan Pernyataan Diri" di atas.

27 Hegel, Lectures, 62.

28 Ibid., 76.
} 
bagian dari proses kesadaran akan ide absolut pada tahap di mana pernyataan diri ini tiba pada sensuous perception. Tahap ini merupakan tahap yang telah melampaui agama natural, tetapi akan segera digantikan oleh tahap rasio murni. Karena pengertian akan hal ini juga Hegel membagi tahap seni mulai dari yang banyak bersentuhan dengan dunia fisik hingga seni yang semakin sedikit berkaitan dengan dunia fisik. ${ }^{29}$ Ini dikarenakan pernyataan diri yang absolut akan terus berproses menuju kepada rasio murni, atau intelektual murni. Maka akan tiba saatnya dimana ide absolut akan berproses dan menuju pernyataan diri yang bukan lagi melalui seni.

\section{Refleksi atas Konsep Hegel}

Konsep Hegel yang secara singkat dibahas di atas merupakan suatu sistem kompleks yang memiliki pengertian yang mengaitkan seni, keindahan, dan ide absolut. Konsep Hegel ini melihat seni sebagai sesuatu yang lebih dalam daripada sekadar ekspresi diri, hiburan, atau tujuan pragmatis. Dengan konsep ini, seni dilihat sebagai sesuatu yang pada dirinya sendiri memiliki keberadaan yang signifikan dan bukan sebagai cara untuk mencapai suatu tujuan tertentu di luar sang absolut. Ada tiga hal yang dapat disimpulkan dari melihat seni secara signifikan, yaitu sebagai pernyataan dari

\footnotetext{
29 Membahas mengenai perkembangan seni yang, menurut Hegel, berkembang dari tahap simbolik menuju klasik, hingga akhirnya romantic. Demikian juga jenis-jenis seni berproses mulai dari arsitektur, sculpture, melukis, musik, dan terakhir adalah puisi. Mulai bergerak ke musik, media fisik menjadi makin berkurang. Kemudian puisi menjadi yang terakhir karena menyampaikan simbol-simbol yang menyampaikan ide yang berkaitan dengan intelek seseorang untuk dinikmati. Ibid., 82-95,
} 
sang absolut.

(1) Seni yang dihasilkan manusia adalah pernyataan individu yang partikular atas pernyataan universal dari sang absolut. Ekspresi seniman akan terabstraksi jika seni yang dia hasilkan tidak dikaitkan dengan sang absolut. Prinsip ini seharusnya mampu mencegah penurunan makna seni menjadi hanya sebagai saluran ekspresi pribadi manusia yang tidak memiliki nilai keindahan universal; dan juga menjaga konsep keindahan menjadi sesuatu yang universal dan bukan bersifat parsial. Di dalam Lectures-nya Hegel berbicara mengenai subyektivitas perasaan dalam menilai keindahan sebagai sesuatu yang berpotensi untuk menuju kepada abstraksi. ${ }^{30}$ Tetapi, di sisi lain, Hegel juga menentang pengabstraksian konsep keindahan menjadi suatu konsep universal yang tidak melihat partikularitas dari seniman maupun seni. ${ }^{31}$ Dengan demikian, kita dapat melihat kekayaan penerapan konsep Hegel dalam pengertiannya yang melihat universal dan partikular secara dialektis. Seni merupakan sesuatu yang mengekspresikan emosi sang seniman sekaligus merupakan suatu pernyataan kesadaran ide absolut sebagai suatu keindahan universal. Baik universalitas keindahan maupun partikularitas seni merupakan dua hal yang tidak dapat dihilangkan bila ingin konsisten dengan konsep Hegel. Demikian juga perpaduan secara dialektis (bukan pendekatan either-or) melihat keragaman dari karya seni sebagai sesuatu yang perlu ada tetapi juga tidak

\footnotetext{
30 Ibid., 38.

31 Ibid., 39-40.
} 
meniadakan adanya prinsip keindahan yang universal. Partikular yang ditempatkan secara tepat dalam universalitas inilah yang menjadikan keindahan dan seni saling berkaitan secara sempurna.

(2) Seni tidak dapat dinikmati dengan diturunkan menjadi sesuatu yang secara pragmatis digunakan demi tujuan lain di luar seni itu sendiri. Seni akan menjadi rusak maknanya bila ditujukan untuk sesuatu yang lain di luar sang absolut. Sebagaimana telah dibahas sebelumnya, seni akan kehilangan fungsi utamanya sebagai wahyu dalam bentuk sensuous artistic bila digunakan untuk tujuan di luar seni itu sendiri. Seni yang digunakan untuk suatu keperluan pragmatis, entah itu untuk relaksasi, mengisi waktu, pendidikan, atau untuk bisnis, akan menarik seni tersebut dari maknanya dalam kaitan dengan ide absolut. Jika kita menganut pengertian secara pragmatis, maka seni akan menjadi sesuatu yang diturunkan dari keindahan asalinya karena digunakan hanya sebagai "alat" untuk tujuan yang lain diluar seni itu sendiri. Memegang pengertian ini atas seni dengan meniadakan pengertian fungsi utama dari seni sebagaimana yang diungkapkan Hegel merupakan suatu bentuk penurunan atas makna seni yang sejati. Keindahan sebagai "alat" tidak boleh dilepaskan dari "sang absolut." Keindahan menjadi salah satu bagian hidup yang diturunkan maknanya dari hal-hal yang dalam dan bermakna, menjadi semacam pengisi kekosongan atau suatu hal sambilan yang dapat menghibur kita selagi kita melakukan hal-hal yang lebih bermakna. Keindahan tidak dianggap setara 
dengan hal-hal yang utama di dalam hidup,32 tetapi hanya merupakan pelengkap yang memperkaya di dalam cara yang kurang substansial. Hegel menolak hal ini dengan memberikan tempat kepada seni sebagai bagian yang sangat penting dari kehidupan, bahkan sebagai bagian yang sangat penting dari seluruh proses yang sedang dialami manusia untuk mengenal yang absolut. Seni bukanlah hal sampingan yang dapat diabaikan. Seni begitu esensial untuk manusia menikmati dan mengenal hal-hal yang lebih dalam daripada dirinya sendiri. Seni dan keindahan adalah hal yang mutlak harus ada di dalam mengaitkan diri manusia dengan hal-hal yang lebih agung daripada dirinya sendiri.

(3) Seni juga tidak bisa dinikmati dengan melepaskannya dari pengertiannya sebagai “usaha dari 'sang absolut' untuk mengaitkan dirinya dengan manusia." Pengertian universal dan prinsip-prinsip absolut bukan hanya sesuatu yang dipahami oleh manusia melalui rasio. Seni dan keindahan juga memiliki fungsi utama untuk menyatakan "sang absolut." Seni dan keindahan bukanlah hanya berkait dengan selera manusia, tetapi merupakan pernyataan "sang absolut." Seni tidak bisa dijadikan kenikmatan pribadi yang individualistik sehingga mengabaikan kaitannya dengan sesuatu yang universal. Tetapi konsep Hegel juga memberikan pengertian keindahan dan seni sebagai sesuatu yang secara personal bermakna. Keindahan bukanlah sesuatu yang dinikmati seseorang tanpa

\footnotetext{
32 William Dyrness, Poetic Theology: God and the Poetics of Everyday Life (Grand Rapids: Eerdmans, 2011), 13.
} 
sentuhan pribadi. Jika seni dinikmati karena dianggap sebagai sesuatu yang universal, maka seni menjadi terabstraksi, bukan dari yang universal, tetapi dari yang partikular, yaitu penikmat-penikmat seni secara individu.

\section{Area Permasalahan Dalam Konsep Hegel}

Area permasalahan dengan konsep Hegelian atas seni ini terletak pada dua hal. Yang pertama adalah kegagalan melihat perbedaan antara "Yang mewahyukan" dengan "cara pewahyuan." Kemudian yang kedua adalah dialektika Hegel ternyata menuju kepada either-or, sehingga mau tidak mau dia harus memilih rasio atau intelektual dengan membuang sensuous artistic.

Pembahasan pertama adalah dengan melihat kesatuan antara ide absolut dengan seni. Hegel ingin menjadikan seni sebagai salah satu dari tiga cara dimana ide absolut bergerak menuju kepada kesadaran diri. Maka, baik agama natural, seni, maupun filsafat merupakan sesuatu yang tidak dapat dilepaskan dari pernyataan diri ide absolut tersebut. Keberadaan realita ini yang adalah keberadaan yang lain dari allah (yaitu ide absolut) dan pernyataan diri yang absolut merupakan pernyataan yang menyatakan diri sebagai yang absolut yang berproses menuju kepada kesadaran diri dimana cara pernyataan diri dari yang absolut ini juga merupakan bagian dari dirinya. Konsep ini dapat dilihat sebagai konsep pantheistic, atau, sebagaimana dikatakan Paul Hidayat, merupakan konsep panentheistic bila ide absolut ini diidentikkan dengan Allah yang kita 
sembah. Tetapi konsep ini dapat juga dilihat sebagai suatu konsep atheistic yang memersonifikasi rasio manusia dimana rasio tersebut akan menjadi sesuatu yang mutlak adanya.

Hal yang kedua adalah pemutlakan rasio dalam konsep Hegel merupakan sesuatu yang tidak terhindarkan. Hegel memiliki pandangan neo-platonis yang tidak terhindarkan, sebagaimana kaum idealis yang lain, dimana segala hal yang berkaitan dengan dunia indera merupakan hal yang inferior ketimbang dunia ide yang non material. Namun Hegel dengan realistis melihat keberadaan dunia ide bukan sebagai keberadaan yang secara paradoks berada di atas dunia materi, sebagaimana pemikiran Plato, tetapi Hegel, dengan sistem yang dia bangun, memasukkan dinamika dan proses ke dalam sistem dialektika dunia ide dan materi versinya sendiri. Tetapi meskipun demikian, dia masih memiliki satu tujuan yang akan dicapai dalam bentuk rasio mutlak yang menyatakan diri. Dalam hal ini kita dapat melihat bahwa ternyata sistem Hegel pun pada akhirnya bersifat either-or dan reduktif sehingga rasio menjadi absolut dan segala hal yang lain, termasuk perasaan sensuous artistic yang memersepsi keindahan seni, hanya menjadi suatu bagian dalam proses yang pada waktunya akan menjadi inferior, atau bahkan menjadi ternegasi, dengan sistemnya yang memutlakkan rasio.

Setelah melihat permasalahan dalam konsep Hegel, maka kita akan melihat bagaimana pengertian Jonathan Edwards menjadi suatu pengertian yang menyempurnakan kelemahan dari sistem Hegel 
mengenai seni dan keindahan. ${ }^{33}$ Dua permasalahan di atas, baik peng-ilah-an seni maupun pemutlakan rasio, menjadi dua permasalahan yang diselesaikan dengan konsep Allah Tritunggalnya, atau lebih spesifik, pembedaan ad intera-ad extra di dalam pembahasan Tritunggalnya.

\section{Jonathan Edwards dan Tujuan Penciptaan}

Setelah melihat konsep Hegel, kita beralih ke dalam pengertian mengenai karya Allah di dalam tulisan Jonathan Edwards, "The End for Which God Created the World"34 Pengertian Edwards mengenai keindahan sejati harus dimengerti dengan melihat apa yang menjadi tujuan penciptaan dunia ini. Edwards melihat keberadaan dunia ini sebagai sesuatu yang memiliki tujuan kepada pernyataan kemuliaan Allah. Allah sendiri menjadikan diri-Nya sebagai tujuan penciptaan karena memang tidak ada apapun diluar diri-Nya yang sebanding untuk dijadikan tujuan penciptaan oleh Allah. Setiap pengenalan akan Allah dan akan karya-Nya harus kembali berfokus kepada kemuliaan Allah. God's glory is the object of this knowledge. ${ }^{35}$ Setiap pengenalan akan Allah harus menuju kepada kesadaran akan kemuliaan Allah sehingga: "...God is glorified in it, as hereby his

\footnotetext{
33 Edwards, sebagaimana Hegel, memiliki suatu konsep yang cukup ambisius dengan berusaha memahami realita dengan mendasarkan seluruh realita diatas satu konsep dasar. Namun, berbeda dengan Hegel, Edwards jauh lebih konsisten ketika dia meletakkan Allah Tritunggal sebagai dasar, dan bukan allah yang hanyalah personifikasi dari rasio absolut. 34 Jonathan Edwards, "The End for which God Created the World," The Works of Jonathan Edwards, 2 vol (Massachusetts: Hendrickson, 2000).
}

35 Ibid., 97. 
excellency is seen." 36 Keberadaan Allah adalah mulia dan segala kesempurnaan ada pada Dia, dan karena itulah Dia harus menjadi tujuan dari penciptaan.

Kemuliaan Allah yang adalah infinite dan tidak terbatas dinyatakan oleh ciptaan secara finite dan terbatas, dimana kesempurnaan kemuliaan Allah menjadi dasar dan sumber dari pernyataan kemuliaan oleh ciptaan-Nya. Dalam Nature of True Virtue Edwards mengatakan bahwa virtue adalah keindahan atau beauty bila diterapkan dalam natur moral. ${ }^{37}$ Tetapi dalam seluruh keberadaan ciptaan, keindahan merupakan sesuatu yang memiliki sumber kembali kepada Allah. Edwards mengatakan:

...benevolence or goodness in the Divine Being is generally supposed, not only to be prior to the beauty of many of its objects, but to their existence; so as to be the ground both of their existence and their beauty, rather than the foundation of God's benevolence; as it is supposed that it is God's goodness which moved him to give them both being and beauty. 38

Mengenai natur keindahan sejati, Edwards mengatakan bahwa

Beauty does not consist in discord and dissent, but in consent and agreement. And if every intelligent being is some way related to being in general, and is a part of the universal system of existence; and so stands in connexion with the whole; what can its general and true beauty be, but its union and consent with the great whole? ${ }^{39}$

\footnotetext{
36 Ibid.

37 Ibid., 122.

38 Ibid., 123.

39 Ibid., 122.
} 
Dalam kalimat ini terlihat kemiripan antara konsep "konkret" Hegel dengan "unison" dari Edwards. Tetapi karena "konkret" Hegel dikaitkan dengan ide absolut, maka apa yang dikemukakannya itu menjadi sempit dan reduktif, sebagaimana telah dibahas di atas. Sebaliknya, karena "unison" Edwards mendasarkan diri pada Allah Tritunggal, maka apa yang dikemukakannya menjadi sesuatu yang limpah dan luas, sebagaimana akan dibahas selanjutnya.

Keindahan yang sejati memiliki sumber dan kaitan dengan keberadaan Allah. Allah bukan saja menjadi sumber keindahan, tetapi seluruh keberadaan, yang adalah repetisi dari disposition Allah secara ad extra, merupakan keberadaan yang memiliki keindahannya dalam kaitannnya dengan seluruh realita ciptaan Allah.

Keindahan sejati merupakan sesuatu yang bersumber dari Allah dan direpetisi dalam dunia ini. Dengan demikian, dunia ini menjadi semacam cara Allah menyatakan keindahan-Nya. Jika Hegel melihat dunia ini sebagai keberadaan yang lain dari Allah, maka Edwards, berbeda dengan Hegel, melihat karya Allah yang merepetisi kemuliaan-Nya dilakukan dalam keberadaan dunia ini, tetapi tidak secara aktual yang sempurna.

Dalam pengertian mengenai opera ad intra, Edwards memberikan suatu pengertian mengenai repetisi kemuliaan Allah secara sempurna dan dinyatakan sekaligus dinikmati di antara Tiga Pribadi Tritunggal. Pengertian ini adalah sesuatu yang menjelaskan mengenai disposition Allah. Baik Bapa, Anak, dan Roh Kudus berbagian di dalam pernyataan kemuliaan yang kekal dan sempurna 
ini. Setiap Pribadi Tritunggal menyatakan kemuliaan-Nya dengan sempurna dan dinikmati oleh Pribadi yang lain dengan sempurna. Allah menyatakan di dalam kekekalan kemuliaan-Nya dengan cara yang kekal dan dengan kesempurnaan aktualitasnya yang infinit, kekal, tidak berubah, dan sempurna.40 Tetapi, dalam ad extra pengertian mengenai disposition Allah yang merepetisi diri-Nya perlu dilihat dengan cara yang berbeda. Di dalam karya ciptaan-Nya, kemuliaan-Nya ini dinyatakan kepada yang terbatas. Karena itu kesempurnaan aktualitas yang infinit, kekal, dan tidak berubah sebagaimana dimengerti dalam ad intra, merupakan hal yang tidak terdapat dalam ad extra. Dengan demikian, perbedaan yang terjadi adalah kesempurnaan kemuliaan Allah tidak direpetisi di dalam ciptaan sebagaimana di dalam ad intra. Tetapi, mengingat bahwa seluruh karya Allah adalah untuk ...reveal His glory,41 maka dapat dikatakan bahwa di dalam ad extra terdapat repetisi kemuliaan Allah tetapi tidak terdapat repetisi kemuliaan sempurna yang total dari Allah. Inilah perbedaan antara konsep Hegel dan Edwards. Hegel tidak melihat pembedaan ad intra-ad extra sebagaimana Edwards melihat.

Yang berikut adalah cara Edwards menggunakan konsep Tritunggalnya jauh lebih konsisten daripada Hegel memperlakukan konsep dialektikanya. Hegel tetap tidak memasukkan secara

\footnotetext{
40 Sang Hyun Lee, "Jonathan Edwards's Dispositional Conception of the Trinity," Toward the Future of Reformed Theology: Tasks, Topics, Traditions. ed. David Willis dan Michael Welker (Grand Rapids: Eerdmans, 1999), 448.
}

41 Stephen R. Holmes, God of Grace and God of Glory (Grand Rapids: Eerdmans, 2000), 41. 
konsisten konsep dialektika sebagaimana seharusnya. Dialektika Hegel lebih kepada dialektika proses yang melihat antitesis antara materi dan ide, maupun antara rasio dan persepsi berada pada kesadaran diri ide absolut yang berada dalam proses. Tetapi Edwards melihat realita ciptaan yang kompleks ini sebenarnya tengah menyatakan kemuliaan Allah Tritunggal yang infinit dengan kapasitas sebagai yang finite. Maka, sebagaimana dalam segi waktu ciptaan memerlukan repetisi dan perkembangan sepanjang keabadian untuk merefleksikan kemuliaan Allah yang tidak terbatas, demikian juga kompleksitas ciptaan ini merupakan sesuatu yang harus ada ketika yang terbatas ini menjadi reflektor atas kemuliaan yang tidak terbatas.42 Dengan demikian, karena ciptaan menjadi repetisi kemuliaan Allah yang tidak terbatas dengan cara yang terbatas, maka ciptaan menjadi repetisi kemuliaan Allah yang terus bertambah hingga kekekalan untuk merepetisi kemuliaan infinite Allah; lalu ciptaan memiliki ragam kompleksitas dan partikularitas yang semuanya adalah untuk menyatakan kemuliaan dari Allah yang infinite. Tidak ada reduksi seni menjadi rasio, atau persepsi menjadi ide di dalam konsep Edwards. Dengan pembedaan repetisi kemuliaan secara ad extra ini, Edwards bebas dari kesalahan Hegel dalam mempertuhankan ciptaan, dan dengan melihat kompleksitas dan ragam dalam ciptaan, Edwards juga secara lebih terbuka melihat ragam cara Allah menyatakan kemuliaan yang tidak hanya direduksi

42 Amy Plantinga Pauw, The Supreme Harmony of All: The Trinitarian Theology of Jonathan Edwards (Grand Rapids: Eerdmans, 2002), 81. 
pada rasio ataupun emosi.

\section{Repetisi Kemuliaan Melalui Kreasi Ciptaan}

Dalam melihat konsep Edwards mengenai ciptaan, maka kita dapat membuat suatu refleksi untuk menarik konsep tersebut ke dalam seni. Edwards melihat keindahan sebagai suatu bentuk pernyataan kemuliaan Allah yang direpetisi oleh ciptaan. Dengan demikian, manusia, sebagai bagian dari ciptaan, juga merepetisi kemuliaan Allah dalam dirinya. Tetapi, berbeda dengan ciptaan lain, manusia yang merepetisi kemuliaan Allah bukan saja menjadi reflektor dari kemuliaan Allah, tetapi juga menjadi pencari kemuliaan Allah tersebut. Edwards mengatakan bahwa:

... a truly virtuous mind ...seeks the glory of God, and makes this his supreme, governing, and ultimate end. This consist in the expression of God's perfections in their proper effects, -the manifestation of God's glory to created understandings - the communications of the infinite fulness of God to the creature. ${ }^{43}$

Dengan demikian, maka manusia menjadi reflektor kemuliaan Allah dengan, salah satunya, menjadi pembuat atau penghasil ekspresi kemuliaan Allah tersebut. Manusia mencari dan merepetisi kemuliaan tersebut sebagai cara untuk memuliakan dan memancarkan kemuliaan Allah. Manusia menjadi pencipta kecil yang menghasilkan sesuatu yang merepetisi kemuliaan Allah. Inilah

43 Jonathan Edwards, The Nature of True Virtue (Ann Arbor: University of Michigan Press, 1996), 127. 
perbedaan seni dengan alam. Seni bukan alam dalam pengertian seni tidaklah menjadi bagian dari karya Allah secara langsung. Manusia menjadi pencipta atas suatu hasil yang merepetisi kemuliaan Allah, tetapi perlu diingat bahwa Allah juga yang bekerja melalui manusia. Baik Hegel maupun Edwards memahami hal ini. Hegel mengatakan bahwa allah bekerja melalui manusia untuk menghasilkan suatu karya seni, ${ }^{44}$ dan Edwards mengatakan bahwa Allah menjadi sumber segala yang baik dan indah, adalah yang memberikan yang baik dan indah itu kepada manusia menjadi milik manusia. ${ }^{45}$ Dari yang baik dan indah inilah manusia menjadi reflektor dalam hidupnya, termasuk di dalam menghasilkan karya seni. Tetapi perbedaan antara keduanya juga sangat signifikan. Hegel menganggap bahwa allah, maupun manusia, maupun karya seni, semuanya memiliki sifat ilahi di dalam pengertian the other self of God yang dia kemukakan, sedangkan Edwards membedakan dengan ketat wilayah ad extra sebagai repetisi kemuliaan yang berbeda dari repetisi ad intra.

Dari konsep Edwards, pengertian seni Hegel dapat dibersihkan dari kesalahan-kesalahan konsep panentheistic. Hegel dengan sangat akurat mengingatkan kita tentang kesalahan melihat seni sebagai cara dengan melupakan tujuan untuk menyatakan sang absolut. Demikian juga seni di dalam kekristenan menjadi tidak berarti jika tidak dimaksudkan untuk menyatakan Sang Pencipta dan Penebus. Jika Allah Tritunggal tidak dinyatakan melalui seni, dan seni

\footnotetext{
44 Hegel, Lectures, 34.

45 Edwards, Nature of True Virtue, 123.
} 
diturunkan hanya sebagai pemuas diri dan sambilan untuk menemani keseharian kita, maka kita telah bersalah di dalam memperlakukan seni. Sebaliknya, sebagaimana diperingatkan oleh pembedaan ad intra-ad extra dari Jonathan Edwards, mengidentikkan seni sebagai pernyataan dari Allah sekaligus being dari Allah sendiri tidak akan membuat seni dinaikkan ke tingkat yang lebih tinggi, melainkan justru akan menurunkan Allah ke level di mana seni tersebut ada, yaitu sebagai karya dari manusia.

Dengan menyempurnakan konsep estetika Hegel dengan pemikiran Jonathan Edwars, maka tiga kesimpulan mengenai seni di dalam pembahasan Hegel dapat tetap diterapkan dan dijaga dari konsep panentheistic Hegel.

(1) Seni adalah pernyataan ekspresi seorang manusia yang berkait dengan responsnya kepada Allah, tetapi tidak dengan memperilah ekspresi tersebut.

(2) Seni merupakan pernyataan keindahan untuk dinikmati dengan maksud menikmati keindahan dan kemuliaan Allah, tetapi dengan memahami bahwa repetisi kemuliaan yang membawa manusia untuk menikmati kemuliaan Allah bukanlah bagian dari diri Allah, dan juga bukanlah sesuatu yang terlepas dari Allah. Tidak ada hal yang baik dapat muncul dari perasaan dekat dengan Allah tanpa menyadari perbedaan antara Diri Allah dan pernyataan kemuliaanNya di dalam ciptaan.

(3) Seni merupakan cara Allah menyatakan diri-Nya dengan cara yang berbeda (tetapi tidak inferior) dari pengertian rasional. 
Menikmati keindahan dengan cara yang berbeda dengan pengertian rasional bukan berarti menikmati Allah dengan cara yang menentang rasio, tetapi menikmati Allah di dalam kelimpahan-Nya yang tidak dimaksudkan untuk diserap dan dinikmati secara rasional.

\section{Kesimpulan: Kekristenan dan Seni}

Setelah melakukan survei singkat terhadap Hegel, kita melihat kepentingan untuk mengaitkan seni kepada sesuatu yang berada di luar manusia itu sendiri. Seni perlu dikaitkan dengan yang absolut. Tetapi permasalahan muncul ketika Hegel mengaitkan seni dengan yang absolut dengan cara yang memutlakkan pernyataan seni, sehingga segala yang terkait dengan seni dan yang absolut merupakan sesuatu yang ilahi, atau, dalam bahasa hegelian, suatu ide absolut yang bergerak kepada kesadaran diri. Tetapi konsep Edwards, walaupun tetap mengharuskan kita untuk mengaitkan seni dengan Allah, tetapi memberikan batasan yang jelas mengenai repetisi kemuliaan Allah yang tidak disertai dengan repetisi being of God. Maka, dengan demikian, pengertian akan seni dan yang absolut selalu dilihat dalam bentuk pernyataan dari manusia akan kemuliaan Allah dalam bentuk kreasi dari manusia untuk merepetisi kemuliaan Allah. Kekristenan harus melihat seni dari sudut pandang seperti ini. Seni yang dilepaskan dari Allah menjadi seni yang tidak bermakna. Segala respons manusia kepada Allah yang sejati yang dituangkan menjadi kreasi seni, itulah yang menyatakan atau merepetisi kemuliaan Allah secara ad extra, dan itulah keindahan sejati di dalam 
seni.

Mengaitkan seni dengan Allah inilah yang banyak terlupakan di dalam kekristenan saat ini. Seni dan keindahan telah diletakkan di dalam dua tempat, baik sebagai yang inferior dari pergumulan intelektual dan pengertian, maupun sebagai yang bersifat "duniawi," dan tidak masuk di dalam realm iman dan ketuhanan. Semua praktek hidup yang dilakukan manusia adalah obyek dari tiga hal yang sama pentingnya, yaitu pemikiran, kehendak, dan afeksi. ${ }^{46}$ Baik berpikir, berencana, dan menikmati rekreasi, kesenangan, dan keindahan seharusnya secara total ditundukkan dan ditujukan kepada Allah yang menyatakan diri-Nya dan kemuliaan-Nya kepada kita semua. Kesalahan gereja-gereja tradisional adalah kurangnya perhatian yang diberikan kepada aspek afeksi terhadap seni dan keindahan. Doktrin yang benar dan etika yang benar tentu bukan sesuatu yang bisa diabaikan dan dianut secara kompromi dengan dunia. Tetapi menikmati keindahan dengan cara yang benar dan sejati juga merupakan aspek yang krusial di dalam kehidupan manusia. Jika gereja tidak memasukkan aspek seni dan keindahan ke dalam deeper issues of life, ${ }^{47}$ maka kebutuhan akan aspek ini harus dicari di luar gereja. Kegagalan gereja-gereja tradisional membuat jemaat tidak terbiasa untuk mendapatkan pemenuhan aspek seni dan keindahan di dalam gereja. Mereka mencarinya di luar. Dan ketika pencarian di

\footnotetext{
46 Bdk. William Dyrness, Poetic Theology: God and the Poetics of Everyday Life (Grand Rapids: Eerdmans, 2011), 5.

47 Ibid., 13.
} 
luar sepertinya memuaskan, mereka akan menemukan bahwa pemuasan ini dapat dipenuhi tanpa harus dikaitkan dengan Allah. Itulah sebabnya kenikmatan dan keindahan menjadi identik dengan dunia, bukan dengan hal-hal yang berkait dengan Allah.

Kegagalan gereja-gereja tradisional ini segera diikuti dengan kebangkrutan gereja-gereja pembaruan. Mereka menyadari bahwa seni dan keindahan tengah dicari oleh orang-orang Kristen di luar gereja. Tetapi bukannya mereka mengembangkan sikap kritis bahwa tawaran budaya sekitar mereka akan keindahan sangat mungkin untuk berbeda total dari apa yang seharusnya dinikmati di dalam kemuliaan Allah, mereka justru dengan gencar membawa tawaran seni dan keindahan dunia itu masuk ke dalam gereja. Tentu saja para penikmat seni dan keindahan dunia itu kembali ke dalam gereja, tetapi mereka tidak lagi menyadari keberadaan seni sebagai bagian dari pernyataan kemuliaan Allah yang agung dan mulia. Mereka tetap membuat abstraksi antara seni dengan Allah. Allah tetap berada di luar seni tersebut karena seni yang diadopsi oleh mereka dari budaya sekeliling mereka merupakan seni yang tidak dimaksudkan untuk dinikmati di dalam Allah. Karena itu entah mereka di luar gereja ataupun di dalam gereja, seni merupakan ekspresi menyenangkan yang dapat dinikmati terpisah dari menikmati Allah dengan benar, konkret, dan bukan abstrak. Seni yang dinikmati sebagai sesuatu yang mencerminkan ekspresi dunia, mencerminkan semangat zaman untuk diterima dan populer, dan mencerminkan hal-hal yang dangkal dan penuh dengan perlawanan terhadap 
kegentaran di hadapan Allah hanyalah membuktikan bahwa kesalahan Hegel mengaitkan seni dengan ilah yang abstrak kembali diulangi oleh gereja.

Kesalahan ketiga yang dilakukan oleh gereja adalah menikmati seni dan menikmati Tuhan tanpa memahami pembedaan ad intra-ad extra. Ketika seseorang menikmati seni dengan menjadikannya tempat pertemuan dengan Allah tanpa pembedaan ad intra-ad extra akan membuat perjumpaannya diwarnai dengan berbagai macam pengalaman other-worldly yang ditafsirkan sebagai kesatuan dengan yang ilahi. Kesatuan tanpa memahami pembedaan ad intra-ad extra tersebut. Kesatuan yang sulit dibedakan dengan keadaan trance mistik dari budaya-budaya penyembahan berhala.

Gereja mempunyai tugas untuk memeriksa keindahan seni yang berada di dalam trend budaya kontemporer sebelum memeluknya ke dalam sebagai bagian dari pernyataan kemuliaan Allah untuk dinikmati anak-anak-Nya. ${ }^{48}$ Tetapi jika gereja gagal menjalankan ini, maka keindahan dan seni akan terus menjadi hal yang terpisah dengan menikmati Allah dengan benar. Jikalau dipaksakan untuk dikaitkan sekalipun, seni hanyalah akan terkait dengan konsep "allah" yang abstrak dan palsu. Maka tetaplah orangorang Kristen mencari kenikmatan dan keindahan sebagaimana ditawarkan dunia hanya untuk menyadari di ujung jalan pencarian

\footnotetext{
48 Dyrness mengatakan, “...if a cultural trend is simply another example of humanity's active hostility to God, surely it must be repudiated rather than engaged. But if, on the other hand, this thirst reflects a deeper longing for an encounter with God, it ought at least to be examined, if not welcomed." Bdk. Ibid., 13.
} 
mereka, bahwa jalan pencarian ini ternyata tidak mempertemukan mereka dengan kemuliaan Allah yang akan memuaskan mereka, tetapi hanya mempertemukan mereka dengan konsep "allah" palsu yang abstrak yang merepetisi suatu kesenangan kosong yang tidak pernah memberikan kepuasan sejati di dalam kemuliaan-Nya. 